\title{
Stepfamily Functioning and Closeness: Children's Views on Second Marriages and Stepfather Relationships
}

\author{
Todd M. Jensen \\ Brigham Young University - Provo \\ Kevin Shafer \\ Brigham Young University - Provo, kshafer@byu.edu
}

Follow this and additional works at: https://scholarsarchive.byu.edu/facpub

Part of the Family, Life Course, and Society Commons

\section{Original Publication Citation}

Jensen, T.M.* \& Shafer, K. (2013). “Stepfamily Functioning and Closeness: Children's Views on Second Marriages and Stepfather Relationships." Social Work, 58(2): 127-136.

\section{BYU ScholarsArchive Citation}

Jensen, Todd M. and Shafer, Kevin, "Stepfamily Functioning and Closeness: Children's Views on Second Marriages and Stepfather Relationships" (2013). Faculty Publications. 4391.

https://scholarsarchive.byu.edu/facpub/4391 


\title{
Stepfamily Functioning and Closeness: Children's Views on Second Marriages and Stepfather Relationships
}

\author{
Todd M. Jensen and Kevin Shafer
}

\begin{abstract}
Current research on stepfamily well-being often overlooks the perspective of children, and deals primarily with factors as reported by the adults involved. The authors examine a number of family role characteristics, parental subsystem characteristics, and resources that might influence how children perceive the quality of their stepfamily relationships. A sample of 1,088 children in households with a mother and stepfather, ages 10 to 16 years, in the National Longitudinal Survey of Youth, 1979 cohort-Children and Young Adult Sample, is used for the analyses. Results indicate that open communication between children and their mothers, low amounts of arguing between mothers and stepfathers, along with agreement on parenting, and gender, all affect the closeness children report having with their stepfathers. Conclusions, limitations, and clinical implications are discussed.
\end{abstract}

KEY WORDS: closeness; relationship quality; stepchildren; stepfamily

S tepfamilies are formed when a parent forms a relationship, either through cohabitation or remarriage, with a partner who is not the biological mother or father of their child or children (Ganong \& Coleman, 2004). Recent estimates of the prevalence of stepfamilies in the United States suggest nearly 10 percent of children live with a stepparent at any given time and a full third will live in a stepfamily before they turn 18 years old (Bumpass \& Raley, 1995; Sweeney, 2010). These patterns are supported by the United States' high divorce and remarriage rate. In fact, the United States has the highest remarriage rate in the world-indicating the relative importance of marital relationships to most Americans (Amato, 2010; Smock, 2000; Sweeney, 2010; U.S. Census Bureau, 2000). Although most individuals think of stepfamilies as being formed through remarriage, an increasingly large number of these families are formed through cohabitation (Goldscheider \& Sassler, 2006). Indeed, cohabitation has become an increasingly frequent precursor and alternative to remarriage, creating a unique stepfamily type (Bumpass, Raley, \& Sweet, 1995; Wu \& Schimmele, 2005). Clearly, these trends have meaningful implications for children. Unfortunately, however, current research has failed to adequately measure children's perceptions of stepfamily life.
Past research has identified how the presence of a stepparent affects children by addressing issues such as school performance, internalized problem behavior, externalized behaviors, and risky behaviors (Coleman, Ganong, \& Fine, 2000). A number of studies have addressed stepfamily quality and the strength of relationships formed through remarriage from the adults' perspective (Sweeney, 2010). In fact, Coleman et al. (2000) estimated that approximately 92 percent of the literature addresses these relatively few topics. Because many scholars see the child-stepparent interaction as central to stepfamily functioning, several scholars have called for greater attention on children's perspectives of stepfamily life, closeness, and quality (Gamache, 1997; Ganong \& Coleman, 2004; Sweeney, 2010). The lack of attention on this topic to date is unfortunate because of the implications that poor family functioning can have for stepchildren. Also, children's perceptions of stepfamily functioning and closeness have significant implications for social workers who work with stepfamilies. The results of our study identify several potentially fruitful places for practitioners to begin working with stepfamilies experiencing a myriad of problems and difficulties.

Using nationally representative data from a sample of children ages 10 to 16 years at time of 
interview, our study focused on closeness between a child and stepfather and its predictors as a way to conceptualize positive stepfamily functioning. As a result, we addressed two gaps in the literature on postdivorce unions and stepfamilies. First, we introduced the viewpoint of children in stepfamilies. Second, our study has significant clinical implications for social workers and other professionals working with stepfamilies-especially if they have children. These clinical insights can support more effective stepfamily formation and improve stepfamily functioning. We used a family systems perspective in our analysis, which shows that the best predictor of a child's closeness with his or her stepfather is how the child views the relationship between his or her mother and stepfather.

\section{FAMILY SYSTEMS THEORY}

Family systems theory, popularized in the 1960s and 1970s, suggests that a family is not merely a collection of individuals, but is defined by the roles, rules, and connections between family members (Bowen, 1978; Minuchin, 1974; Satir, 1967; Satir \& Baldwin, 1983; Satir, Stachowiak, \& Taschman, 1977). Relevant in research and clinical settings, the theory essentially argues that the family as a whole is greater than the sum of its parts (Day, 2010). Each family has its own unique structure, boundaries, rules, roles, resources, subsystems, and goals. Families best attain healthy methods of functioning through homeostasis-where stagnation and rapid change are balanced against one another. Stepfamily formation can be a period of intense change that generates imbalance and disharmony within a family. Roles, rules, subsystems, resources, and other aspects of family life can undergo drastic changes through family dissolution and reformation by means of cohabitation or remarriage with a new partner. However, a family systems perspective would suggest that stepfamilies may be successful if they balance this change with some level of stability and adaptability. The level of stability achieved by a family may rest on the quality of the relationship between adults, how the family was formed, and whether there is a cohabiting or marital union. We address these issues further in our discussion later.

\section{CHILDREN'S REACTIONS TO STEPFAMILIES}

The vast majority of stepfamilies are formed after divorce. As such, the dynamics of stepfamily formation and postdivorce life are important to consider (Ganong \& Coleman, 2004). Timing to stepfamily formation may be one important characteristic that affects functioning. For example, Hetherington and Kelly (2002) found that the emotional and psychological well-being of children from divorce was correlated with time between dissolution and remarriage. Likewise, children's attitudes toward a stepfamily may be influenced by their age (Ganong \& Coleman, 2004). Perhaps more significant is the role that coparenting between biological parents plays in stepfamily life. Often, mothers receive sole custody or primary custody of their children, and the biological father does not reside with the child or children (Goldscheider \& Sassler, 2006). In such scenarios, the involvement of a biological father in his children's lives is crucial. Consistent contact and a close relationship with a biological father can mediate many of the negative emotional, psychological, and social behaviors that children of divorce often engage in (Amato \& Booth, 1996; Amato \& Keith, 1991; Cummings \& Davies, 1994). How a positive relationship with a biological father influences attitudes toward a stepfather is less well known. On the one hand, children with absent fathers may seek out a fatherly relationship with their mother's new partner as a coping strategy. On the other hand, disconnection with one's biological father may produce significant distrust of all men attempting to take on fatherhood. Alternatively, children who are close with their biological father may have a better attitude toward their stepfather or see their mother's new partner in a negative light. Nevertheless, it seems reasonable to suggest that coparenting dynamics between expartners can influence how a child perceives the quality of his or her stepfamily relationships.

Another factor that could influence relationships within the stepfamily is whether the relationship was formed through cohabitation or remarriage. Relationships between stepchildren and stepfathers may be hampered in cohabiting relationships for several reasons. First, cohabiting couples tend to be less committed to one another than married couples and are more likely to dissolve their relationships than others who marry (Manning \& Brown, 2006). Cohabiters rarely pool their economic resources, and parenting responsibilities are less clear in cohabitation than in marriage (Heimdal \& Houseknecht, 2003). Likewise, cohabiters typically 
report lower relationship quality than married couples and have selective characteristics that could influence relationships within a newly formed family (Brown \& Booth, 1996; Xu, Hudspeth \& Bartkowski, 2006). This uncertainty can have negative effects on children. For example, Brown (2006) found that children in cohabiting stepfamilies have poorer psychological health, have more behavioral problems, and do worse in school than children in remarried stepfamilies. However, not all cohabiting relationships may negatively affect stepfather-child relationships. For one, cohabiting relationships are complex and not easily categorized (Cherlin, 2010). Furthermore, Ganong and Coleman (2004) suggested that children's perceptions of commitment between their mother and stepfather may be a more important factor than the type (cohabiting versus married) relationship-this sentiment has also been echoed in other work (King, 2009). Sweeney (2010) concluded that research comparing postdivorce cohabitation and remarriage are inconsistent and lack a focus on relational outcomes for children. Our study should make a valuable contribution to this area.

One other potentially significant predictor of positive stepchild-stepfather relationships is the quality and stability of the new adult partnership. In a recent review of the literature, Falke and Larson (2007) found that positive postdivorce relationships are forged by agreement on important topics, financial security, and significant social support. Conversely, they found that economic strain, emotional attachment with an ex-spouse, and complex and unclear stepfamily roles have a negative influence on relationship quality. Although these factors can affect children, it is perhaps more important to consider how a child perceives the quality of the relationship between his or her mother and stepfather. Some factors, such as how they agree on parenting, the frequency of arguments between the couple, the perceived quality of the mother-stepfather relationship, and open family communication could strengthen the bond between a child and his or her stepfather.

\section{CURRENT STUDY}

Our study examined the factors that predict stepfamily relationship quality for children, which we operationalize as the degree of closeness between the child and his or her stepfather. Our questions are significant because they will help identify more appropriate and desirable social norms for stepfamilies, which have commonly been seen as ambiguous or nonexistent (Cherlin, 1978, 2004). More important, this study provides clinical insights on how stepfamily relationships can be more satisfying for children, rather than solely viewing children as victims of stepfamily pathology.

After reviewing the literature and using a family systems perspective, we identified three research questions:

1. What family roles will contribute to an increase in stepfamily relationship quality for children?

2. What parental subsystem characteristics will increase levels of stepfamily relationship quality for children?

3. What resources will contribute to an increase in stepfamily relationship quality for children?

\section{DATA AND METHOD}

We used data from the National Longitudinal Survey of Youth, 1979 cohort-Children and Young Adult Sample (henceforth, NLSY-CYA). This sample consists of the biological children born to female respondents from the main NLSY79 sample. The NLSY79 is a nationally representative random sample of individuals who were 14 to 22 years old on January 1, 1979, surveyed between 1986 and 2008; the NLSY-CYA is a representative sample of children born to women from this cohort. NLSY began data collection with children in 1986, which includes demographic, developmental, and attitudinal information. Because data come from child respondents of women in the NLSY79 data, the two data sets can be linked, providing rich information about family life from both a child's and an adult's perspective. Ten- to 16-year-old respondents were asked questions about familial interaction once in the survey. Children eligible for our study were born between 1976 and 1998. To test for potential issues resulting from the respondents taking the survey in different years, we included control variables for year born and year interviewed in a nonreported model. Both effects were nonsignificant.

NLSY-CYA respondents were interviewed from 1986 to 1994 through face-to-face interviews and were asked a series of closed-ended questions on a myriad of topics. Since 1994, the data have 
been collected using computer-assisted personal interviewing interview procedures. The data include a number of assessments-including a number of child development assessments, questions about attitudes, feelings, and relationships, behavioral data, and so forth. The data are commonly used and highly reliable (Center for Human Resources Research, 2005).

We restricted our sample by limiting our data to children who made their primary residence with mothers who entered a cohabiting or marital relationship after divorce. Some respondents come from the same mother and may have similar experiences, ultimately biasing the data in one direction. We tested for potential bias in the estimation of our models which resulted from having siblings in the data, but our results were substantively similar to those presented here. Our final analytical sample included 1,088 respondents.

\section{Dependent Variable}

Detail on all variables is provided in Table 1. Although research on stepparent-child closeness is relatively rare (but see King, 2009), our measure is relatively standard in the literature, though more expansive than questions available in other data sets. Our dependent variable is constructed from seven items that measure child closeness to their stepfather: (1) I discuss important decisions with my stepfather; (2) my stepfather listens to my side of the argument; (3) my stepfather knows where I am when not at home; (4) I spend time with my stepfather; (5) my stepfather often misses important events or activities (reverse coded); (6) I feel close to my stepfather; (7) I share important ideas and talk about important things with my stepfather. Responses were coded on a scale from 1 (hardly ever) to 3 (often). We recoded these responses to range between 0 and 2 , with the final variable ranging between 0 and 14 . The alpha on this measure $(\alpha=0.75)$ was good and indicated high reliability and validity between the items.

\section{Key Independent Variables}

Using family systems theory, we include a number of variables that have been identified as important to predict stepfather-child closeness in our model. It is worth noting that the variables we used in our analyses are not scaled but are grouped for theoretical reasons and conceptual suitability. Family roles are assessed by variables for child's gender, cohabitation status, child's perceived ability to discuss issues regarding the stepfather with mother, and a set of dichotomous variables for mother's employment. Parental subsystems were measured with four dichotomous variables indicating that the child feels the mother-stepfather relationship is good, that the mother and stepfather agree on parenting, and the mother and stepfather argue infrequently (reverse coded). There is some suggestion that contact with a biological parent may influence the stepparent-child relationship (Ganong \& Coleman, 2004). As a result, we included a dichotomous variable indicating that the child has frequent contact with his or her biological father. Resources are measured through several sets of dichotomous variables for mother's education, stepfather's education, religious affiliation, and frequent attendance (at least once a week) at religious services. A variable for income, which was adjusted to 2008 dollars and logged for positive skew, was also been included.

\section{Control Variables}

To address differences in timing effects, we included control variables for child's age at interview and years the mother has been in her current relationship - both of which were measured continuously. King (2009) showed significant differences in closeness based on racial and ethnic identification. Thus, we included dichotomous variables for child's self- identified race. Finally, the ability to develop a close relationship with a stepfather may be associated with the number of children in the household - an effect we controlled for with a continuous variable measured at time of interview.

\section{Analytic Strategy}

We use standard ordinary least squares (OLS) regression to estimate the relationships between our independent variables and closeness between stepfather and child. Given our focus on family roles, parental subsystems, and resources, we considered alternative methodological strategies to OLS. Namely, we considered the use of structural equation modeling (SEM) to answer our research questions. However, SEM would have been ineffective for the following four reasons: (1) we ran an exploratory factor analysis, which produced no meaningful results; (2) family systems theory does not specify empirical constructs; (3) the types of roles, subsystems, and resources we included 
Table 1: Sample Characteristics for All Variables and Mean Closeness for Independent and Control Variables, Averaged Over Imputed Values $(N=1,087)$

\begin{tabular}{|c|c|c|c|c|c|c|}
\hline \multirow[b]{2}{*}{ Variable } & \multicolumn{2}{|c|}{$\begin{array}{l}\text { Sample } \\
\text { Characteristics }\end{array}$} & \multicolumn{2}{|c|}{$\begin{array}{l}\text { Closeness if } \\
\text { Variable = } 1\end{array}$} & \multicolumn{2}{|c|}{$\begin{array}{l}\text { Closeness if } \\
\text { Variable = } 0\end{array}$} \\
\hline & $M$ & SE & $M$ & SE & $M$ & SE \\
\hline \multicolumn{7}{|l|}{ Dependent variable } \\
\hline Child closeness to stepfather & 6.81 & 0.62 & - & - & - & - \\
\hline \multicolumn{7}{|l|}{ Family roles } \\
\hline Child is female & 0.53 & 0.02 & 8.24 & 3.55 & 9.22 & $3.11^{*}$ \\
\hline Cohabiting stepfamily & 0.18 & 0.01 & 8.66 & 3.06 & 8.72 & 3.45 \\
\hline Can talk about stepfather with mother & 0.81 & 0.01 & 8.84 & 3.37 & 8.05 & $3.37^{*}$ \\
\hline \multicolumn{7}{|l|}{ Mother's employment } \\
\hline Full-time employed & 0.56 & 0.02 & 8.81 & 3.44 & 8.55 & 3.30 \\
\hline Part-time employed & 0.27 & 0.02 & 8.56 & 3.22 & 8.75 & 3.44 \\
\hline Not employed outside home & 0.17 & 0.01 & 8.52 & 3.46 & 8.73 & 3.37 \\
\hline \multicolumn{7}{|l|}{ Parental subsystems } \\
\hline Mother-stepfather relationship good & 0.77 & 0.02 & 8.89 & 3.29 & 7.88 & $3.65^{*}$ \\
\hline Mother and stepfather agree on parenting & 0.69 & 0.02 & 9.13 & 3.28 & 7.08 & $3.26^{*}$ \\
\hline Mother and stepfather argue infrequently & 0.76 & 0.02 & 9.02 & 3.25 & 7.57 & $3.60^{*}$ \\
\hline Frequent contact with biological father & 0.76 & 0.02 & 8.55 & 3.32 & 9.11 & 3.54 \\
\hline \multicolumn{7}{|l|}{ Resources } \\
\hline \multicolumn{7}{|l|}{ Mother's education } \\
\hline Less than high school & 0.19 & 0.01 & 8.30 & 3.04 & 7.77 & $3.44^{*}$ \\
\hline High school graduate & 0.49 & 0.01 & 8.75 & 3.52 & 8.65 & 3.27 \\
\hline Some college & 0.21 & 0.01 & 8.93 & 3.38 & 8.64 & 3.39 \\
\hline College graduate & 0.11 & 0.01 & 8.61 & 3.33 & 8.72 & 3.40 \\
\hline Log of family income & 9.85 & 1.70 & - & - & - & - \\
\hline \multicolumn{7}{|l|}{ Stepfather's education } \\
\hline Less than high school & 0.10 & 0.01 & 9.10 & 2.91 & 8.66 & 3.43 \\
\hline High school graduate & 0.67 & - & 8.28 & 3.36 & 8.89 & 3.38 \\
\hline Some college & 0.13 & 0.01 & 8.75 & 3.60 & 8.69 & 3.35 \\
\hline College graduate & 0.10 & 0.01 & 7.98 & 3.38 & 8.81 & 3.37 \\
\hline \multicolumn{7}{|l|}{ Child's identified religious affiliation } \\
\hline Catholic & 0.12 & 0.01 & 9.03 & 3.25 & 8.52 & 3.44 \\
\hline Conservative Protestant & 0.44 & 0.01 & 8.53 & 3.45 & 8.72 & 3.35 \\
\hline Mainline Protestant & 0.21 & 0.01 & 8.91 & 3.29 & 8.66 & 3.40 \\
\hline No religious affilation & 0.06 & 0.01 & 5.85 & 3.68 & 6.80 & $3.71^{*}$ \\
\hline Other religious affiliation & 0.17 & 0.01 & 7.97 & 3.59 & 8.81 & $3.34^{*}$ \\
\hline Frequently attends religious services & 0.37 & 0.02 & 8.65 & 3.46 & 8.73 & 3.34 \\
\hline \multicolumn{7}{|l|}{ Control variables } \\
\hline Child's age at interview & 13.90 & 0.09 & - & - & - & - \\
\hline Years mother in new relationship & 4.97 & 0.16 & - & - & - & - \\
\hline \multicolumn{7}{|l|}{ Child's race and ethnicity } \\
\hline Non-Hispanic black & 0.37 & 0.02 & 8.73 & 3.87 & 8.68 & 3.89 \\
\hline Non-Hispanic white & 0.48 & 0.01 & 8.65 & 3.43 & 8.76 & 3.33 \\
\hline Hispanic & 0.14 & 0.01 & 8.82 & 3.22 & 8.68 & 3.41 \\
\hline Number of children in household & 1.15 & 0.04 & - & - & - & - \\
\hline
\end{tabular}

Note: We do not report mean closeness for continuous variables because there is no logical dichotomy to observe differences.

Source: National Longitudinal Survey of Youth, Children and Young Adult Sample.

${ }^{*} p<.05$, two-sample $t$ test.

do not necessarily measure the same thing, nor would we expect them to; and (4) we were not specifically testing a theory but were using theory as a way to organize our results.
We used multiple imputation techniques to handle missing data from nonresponse (Rubin, 1987) with the mi command in Stata 12. Child respondents frequently did not answer all of the 
closeness questions by indicating that they did not know or did not desire to answer the question. We included respondents with at least two valid responses on the seven-item dependent measure. There did not appear to be any pattern to missing data, suggesting the missing values were either missing completely at random or missing at random. In both situations, multiple imputation is an appropriate method for handling missing data (Enders, 2010). Although imputing on the dependent variable is not without controversy (von Hippel, 2007), it has become an increasingly accepted practice to estimate the effect of independent variables on an imputed dependent variable. This allows us to analyze our data on the eligible sample of 1,088 . We ran models using listwise deletion (nonimputed) procedures for comparison $(n=442)$. The results are substantially similar to one another, and any differences between the nonimputed and imputed models appear to result from misspecification of the standard errors in the nonimputed case. Thus, the results in our imputed model are somewhat more conservative than they are in the nonimputed model. Largely, however, there is little substantive difference between the two models.

We used a nested-modeling strategy, in which we estimated the effects of our family roles (model 1), parental subsystems (model 2), and resources (model 3) variables separately. We then modeled all of these variables together (model 4). Finally, we included a model with all variables, including statistical controls, incorporated (model 5).

\section{Sample Characteristics}

We report the estimated sample characteristics, averaged over five imputations, in Table 1. The average closeness between a child and stepfather is 6.81. Our sample is slightly more female than male, slightly less than 20 percent of the relationships were formed through cohabitation, and most children believed they could discuss issues about their stepfather with their mother. The majority of mother's have outside employment. Our three measures of mother-stepfather relationship quality, as indicated by the child, range between 69 percent to 77 percent agreement. Nearly three-quarters of our sample has frequent contact with their biological father. A plurality of mothers and a majority of stepfathers graduated from high school. Most children identified as conservative Protestant or mainline Protestant, slightly more than one-third attended religious services frequently. The average child was about 14 years old, white, and the only child in the household. New relationships averaged about five years in length at the time of interview.

\section{RESULTS}

\section{Descriptive Findings}

We report the means and standard deviations, where applicable, in Table 1. In this table, we provide the mean score for dichotomously measured variables in our model. We do not include mean closeness for continuously measured variables, because they lack a proper comparison point. Two-sample $t$ tests were conducted for statistically significant differences on each variable. Girls had lower levels of closeness to their stepfathers than did boys. We also found statistically significant differences on all four of our parental relationship variables. Children who reported high relationship quality, agreement on parenting, infrequent arguing, and an ability to discuss things openly all reported they are relatively close with their stepfathers. Among our control variables, we only found statistically significant differences if the mother did not graduate high school or if the family has an "other" religious affiliation. In the former case, closeness is higher, and it is lower on the latter. Given these results, we continue our discussion with findings from our regression models in the next section.

\section{Regression Findings}

The OLS regression results for our model of child's closeness to stepfather are reported in Table 2. These results were obtained from averages over five imputations, as estimated by Stata 12. Model 1 reports the effects of family role variables without any controls. Girls reported closeness levels 0.802 points lower than did boys. Children who believed they could discuss problems or issues related to their stepfather with their mother reported closeness levels 0.979 points higher, on average, than children who believed they could not have such discussions. The other variables were not statistically significant.

Model 2 reports the effect of parental subsystem variables. Here, agreement on parenting and infrequent arguing had strong effects. Each produced average increases in closeness of 2.029 and 1.005 points, respectively. Model 3 addresses the effects 
Table 2: OLS Regression Results of Stepfather-Child Closeness on Independent and Control Variables, Averaged over Imputed Values

\begin{tabular}{|c|c|c|c|c|c|c|c|c|c|c|}
\hline & \multicolumn{2}{|c|}{ Model 1} & \multicolumn{2}{|c|}{ Model 2} & \multicolumn{2}{|c|}{ Model 3} & \multicolumn{2}{|c|}{ Model 4} & \multicolumn{2}{|c|}{ Model 5} \\
\hline & $\boldsymbol{\beta}$ & SE & $\boldsymbol{\beta}$ & SE & $\boldsymbol{\beta}$ & SE & $\boldsymbol{\beta}$ & SE & $\boldsymbol{\beta}$ & SE \\
\hline \multicolumn{11}{|l|}{ Family roles } \\
\hline Child is female & -0.802 & 0.220 & & & & & -0.858 & $0.233^{* *}$ & -0.947 & $0.267^{* *}$ \\
\hline Cohabiting stepfamily & -0.340 & 0.287 & & & & & -0.094 & 0.380 & 0.016 & 0.376 \\
\hline Can talk about stepfather with mother & 0.979 & $0.249^{* * *}$ & & & & & 0.953 & $0.355^{*}$ & 1.096 & $0.371^{*}$ \\
\hline \multicolumn{11}{|l|}{ Mother's employment } \\
\hline \multicolumn{11}{|l|}{ (Mother employed full-time) } \\
\hline Mother employed part-time & -0.281 & 0.290 & & & & & -0.370 & 0.385 & -0.297 & 0.452 \\
\hline Mother does not work outside home & -0.325 & 0.423 & & & & & -0.090 & 0.503 & -0.059 & 0.649 \\
\hline \multicolumn{11}{|l|}{ Parental subsystems } \\
\hline Mother-stepfather relationship good & & & 0.418 & 0.304 & & & 0.469 & 0.292 & 0.661 & $0.327^{\dagger}$ \\
\hline Mother and stepfather agree on parentin & & & 2.029 & 0.679 & & & 2.026 & $0.706^{*}$ & 1.789 & $0.443^{* *}$ \\
\hline Mother and stepfather argue infrequentl & & & 1.005 & $0.256^{* * *}$ & & & 0.832 & $0.261^{* *}$ & 0.698 & $0.257^{* *}$ \\
\hline Frequent contact with biological father & & & -0.457 & 0.339 & & & -0.472 & 0.349 & -0.470 & 0.360 \\
\hline \multicolumn{11}{|l|}{ Resources } \\
\hline \multicolumn{11}{|l|}{ Mother's education } \\
\hline \multicolumn{11}{|l|}{ (High school graduate) } \\
\hline Attended college & & & & & 0.313 & 0.275 & 0.253 & 0.381 & 0.374 & 0.459 \\
\hline College graduate & & & & & 0.017 & 0.347 & -0.146 & 0.369 & -0.095 & 0.338 \\
\hline Log of family income (in 2008 dollars) & & & & & 0.095 & 0.074 & 0.089 & 0.079 & 0.074 & 0.065 \\
\hline \multicolumn{11}{|l|}{ Stepfather's education } \\
\hline (Did not graduate high school) & & & & & 0.131 & 0.328 & 0.031 & 0.432 & 0.192 & 0.413 \\
\hline \multicolumn{11}{|l|}{ High school graduate } \\
\hline Attended college & & & & & 0.209 & 0.392 & 0.283 & 0.544 & 0.222 & 0.542 \\
\hline College graduate & & & & & -0.710 & $0.396^{\dagger}$ & -0.386 & 0.513 & -0.521 & 0.488 \\
\hline \multicolumn{11}{|l|}{ Child's identified religious affiliation } \\
\hline (Catholic) & & & & & 0.030 & 0.252 & 0.226 & 0.312 & 0.433 & 0.361 \\
\hline \multicolumn{11}{|l|}{ Conservative Protestant } \\
\hline Mainline Protestant & & & & & 0.534 & 0.337 & 0.768 & 0.466 & 0.788 & 0.500 \\
\hline No religious affiliation & & & & & -0.533 & 0.480 & -0.499 & 0.550 & -0.532 & 0.641 \\
\hline Other religious affiliation & & & & & -0.529 & 0.318 & -0.405 & 0.355 & -0.331 & 0.413 \\
\hline Frequently attends religious services & & & & & 0.192 & 0.301 & 0.200 & 0.408 & 0.317 & 0.412 \\
\hline \multicolumn{11}{|l|}{ Control variables } \\
\hline Child's age at interview & & & & & & & & & -0.428 & 0.445 \\
\hline Years mother in new relationship & & & & & & & & & -0.041 & 0.034 \\
\hline \multicolumn{11}{|l|}{ Child's race and ethnicity } \\
\hline Non-Hispanic black & & & & & & & & & 0.279 & 0.405 \\
\hline \multicolumn{11}{|l|}{ (Non-Hispanic white) } \\
\hline Hispanic & & & & & & & & & 0.218 & 0.418 \\
\hline Number of children in household & & & & & & & & & -0.142 & 0.089 \\
\hline Intercept & 7.153 & & 4.929 & & 6.365 & & 3.785 & & 9.881 & \\
\hline$N$ & 1,087 & & 1,087 & & 1,087 & &, 087 & &, 087 & \\
\hline Estimated $R^{2}$ & 0.027 & & 0.099 & & 0.021 & & 0.154 & & 0.286 & \\
\hline
\end{tabular}

Note: Reference categories are in parentheses.

Source: National Longitudinal Survey of Youth, Child and $Y$ oung Adult Sample. ${ }^{* * *} p<.001 .{ }^{* *} p<.01 .{ }^{*} p<.05 .+p<.10$ (two-tailed tests).

of resources and shows little to no statistical significance. In fact, only "stepfather is a college graduate" had any significant effect-and it was marginal. If the stepfather is a college graduate, closeness is 0.710 points lower, compared with stepfathers who are high school graduates. 
Model 4 includes family roles, parental subsystem, and resource variables together. The results are largely similar to those produced in models 1 through 3, with three notable differences: (1) the statistical significance of talking about the stepfather has been moderated; (2) a similar effect is observed for infrequent arguing between the mother and the stepfather; (3) the effect of stepfather's education is no longer marginally significant.

Finally, model 5 replicates model 4 but includes statistical controls. The results show larger negative and positive effects for being female and talking about the stepfather than either models 1 or 4 , respectively. Relationship quality between the mother and the stepfather is now marginally significant. A child reporting good relationship quality results in a 0.661 increase in closeness. Agreement on parenting and infrequent arguing remain positive, but the magnitude of the effects has been slightly reduced from model 4 . No other variables were statistically significant in model 5 .

\section{CONCLUSION}

The purpose of this study was to assess the influence of specific family role characteristics, parental subsystem characteristics, and family system resources on the quality of stepfamily relationships for children. We found that variables related to family roles and parental subsystem characteristics were the most influential in terms of how close children reported being to their stepfathers. Variables dealing with family resources were not found to be very meaningful. This highlights the importance of factors pertaining more intimately to who family members are and how they interact with each other in the assessment of how children perceive the quality of their stepfamily relationships.

In terms of family roles, when children perceive their mothers as responsive, open, and available, children are able to experience more stability and consistency (equilibrium) during dramatic family system changes. This role continuation can increase the likelihood that the children and stepfather will grow close. Furthermore, when children view their mother as accessible in terms of communication about their stepfather, they might be less prone to hold resentful feelings toward their stepfathers and thus be able to draw closer to them. As for gender, stepdaughters are less likely to attain closeness to their stepfathers than are stepsons. The roles associated with stepsons and stepdaughters are qualitatively different, and stepsons might find it easier to trust the presence of a new man in their home when compared with stepdaughters.

When examining parental subsystem characteristics, we found them to be quite meaningful in how close children reported being with their stepfathers. Specifically, when children feel that mothers and stepfathers are agreeable in terms of their parenting, and infrequently argue, the children are more likely to attain closeness to their stepfathers. These findings are congruent with previous research showing that remarriage quality is connected to partners agreeing on important topics (Falke \& Larson, 2007). So, when children see a mother and a stepfather form a strong, united, and cooperative parental subsystem, the children are better able to adapt to family structure changes and are more open to connect with their new stepfather.

As we assessed family resource variables, we found that none of the factors examined had any significant predictive power on how children assess the quality of their stepfamily relationships. This seems to be an indication that the interpersonal factors inherent in stepfamily life are more meaningful than external resources when it comes to how children view the quality of their stepfamily relationships. Although external resources might remain important to family functioning, it seems that children may be more concerned with how well their mothers and stepfathers get along and with how much they can still communicate with their mothers once a stepfamily has been formed.

\section{Limitations}

Our study should be tempered by its limitations. First, even though our sample was derived from a longitudinal data set, we were unable to conduct longitudinal analyses because the children in the sample were only asked to respond to the survey at one time point. This reduced the strength of our analytical approach. Also, due to the limitations of the data set, we were only able to assess stepfamilies consisting of a mother and a stepfather, as opposed to father-stepmother households. Lastly, our sample consisted of the children of mothers born between 1957 and 1965, leaving room for possible cohort effects. 


\section{Implications}

Although our findings may seem intuitive to many, little research has focused on how close stepparent-child relationships are formed. However, we feel that our empirical investigation can provide important information for clinicians working with stepfamilies. First, when clinicians desire to help stepfamilies reach higher levels of functioning and relationship satisfaction, they should direct some of their attention to the quality of the new partnership. Clinicians should address the importance of seeing eye-to-eye on how to parent while minimizing open disagreement and arguing. Many individuals may think that when their relationship is positive, all else will fall into place. Our findings suggest that clinicians should try to find balance between the couple and their children. Second, clinicians should pay attention to how ties between biological parents and their children change during stepfamily formation. In some cases it would be wise for clinicians to advise biological parents to allow open communication between themselves and their children, particularly in regard to the new stepparent. Many parents are not open to discussion about the stepparent (Wallerstein \& Kelly, 1980), and our results suggest that this will have a negative effect on a desirable outcome. Third, our results suggest that there is not a one-size-fits-all approach with children. Clinicians should pay close attention to how female and male children differ in their ability and desire to form close relationships with their stepfather. Female children might struggle with stepfamily cohesion more than male children do. $\mathbf{5 W}$

\section{REFERENCES}

Amato, P. R. (2010). Research on divorce: Continuing trends and new developments. Journal of Marriage and Family, 72, 650-666.

Amato, P. R., \& Booth, A. (1996). A prospective study of parental divorce and parent-child relationships. Journal of Marriage and the Family, 58, 356-365.

Amato, P. R., \& Keith, B. (1991). Parental divorce and adult well-being: A meta-analysis. Journal of Marriage and the Family, 53, 43-58.

Bowen, M. (1978). Family therapy in clinical practice. New York: Jason Aronson.

Brown, S. L. (2006). Family structure transitions and adolescent well-being. Demography, 43, 447-461.

Brown, S. L., \& Booth, A. (1996). Cohabitation versus marriage: A comparison of relationship quality. Journal of Marriage and the Family, 58, 668-678.

Bumpass, L. L., \& Raley, R. K. (1995). Redefining singleparent families: Cohabitation and changing family realities. Demography, 32, 97-109.

Bumpass, L. L., Raley, R. K., \& Sweet, J. A. (1995). The changing character of stepfamilies: Implications of cohabitation and nonmarital childbearing. Demography, 32, 425-436.

Center for Human Resources Research. (2005). NLS handbook. Columbus: Ohio State University.

Cherlin, A. J. (1978). Remarriage as an incomplete institution. American Journal of Sociology, 84, 634-650.

Cherlin, A. J. (2004). The deinstitutionalization of American marriage. Journal of Marriage and Family, 66, 848-861.

Cherlin, A. J. (2010). Demographic trends in the United States: A review of research in the 2000s. Journal of Marriage and Family, 72, 403-419.

Coleman, M., Ganong, L., \& Fine, M. (2000). Reinvestigating remarriage: Another decade of progress. Journal of Marriage and Family, 62, 1288-1307.

Cummings, E. M., \& Davies, P. (1994). Child and marital conflict: The impact of family dispute and resolution. New York: Guilford Press.

Day, R. D. (2010). Introduction to family processes (5th ed.). New York: Routledge Taylor \& Francis Group.

Enders, C. K. (2010). Applied missing data analysis. New York: Guilford Press.

Falke, S. I., \& Larson, J. H. (2007). Premarital predictors of remarital quality: Implications for clinicians. Contemporary Family Therapy, 29, 9-23.

Gamache, S. J. (1997). Confronting nuclear family bias in stepfamily research. In I. Levin, \& M. B. Sussman (Eds.), Stepfamilies: History, research, and policy (pp. 41-70). New York: Haworth Press.

Ganong, L. H., \& Coleman, M. (2004). Stepfamily relationships. Development, dynamics, and interventions. New York: Kluwer Academic Publishers/Plenum Press.

Goldscheider, F., \& Sassler, S. (2006). Creating stepfamilies: Integrating children into the study of union formation. Journal of Marriage and Family, 68, 275-291.

Heimdal, K., \& Houseknecht, S. (2003). Cohabiting and married couples' income organization: Approaches in Sweden and the United States. Journal of Marriage and Family, 65, 525-538.

Hetherington, E. M., \& Kelly, J. (2002). For better or for worse: Divorce reconsidered. New York: W. W. Norton.

King, V. (2009). Stepfamily formation: Implications for adolescent ties to mothers, nonresident fathers, and stepfathers. Journal of Marriage and Family, 71, 954-968.

Manning, W. D., \& Brown, S. (2006). Children's economic well-being in married and cohabiting parent families. Journal of Marriage and Family, 68, 345-362.

Minuchin, S. (1974). Families and family therapy. Cambridge, MA: Harvard University Press.

Rubin, D. (1987). Multiple imputation for nonresponse in surveys. New York: John Wiley \& Sons.

Satir, V. (1967). Conjoint family therapy. Palo Alto, CA: Science and Behavior Books.

Satir, V., \& Baldwin, M. (1983). Satir step by step. Palo Alto, CA: Science and Behavior Books.

Satir, V., Stachowiak, J., \& Taschman, H. (1977). Helping people change. New York: Jason Aronson.

Smock, P. J. (2000). Cohabitation in the United States: An appraisal of research themes, findings, and implications. Annual Review of Sociology, 26, 1-20.

Sweeney, M. M. (2010). Remarriage and stepfamilies: Strategic sites for family scholarship in the 21 st century. Journal of Marriage and Family, 72, 667-684.

U.S. Census Bureau. (2000). Statistical abstract of the United States. Washington, DC: U.S. Department of the Treasury.

von Hippel, P. T. (2007). Regression with missing Ys: An improved strategy for analyzing multiply imputed data. Sociological Methodology, 37(1), 83-117. 
Wallerstein, J. S., \& Kelly, J. B. (1980). Surviving the breakup: How children and parents cope with divorce: Basic Books.

Wu, Z., \& Schimmele, C. M. (2005). Repartnering after first union disruption. Journal of Marriage and Family, 67, 27-36.

Xu, X., Hudspeth, C. D., \& Bartkowski, J. P. (2006). The role of cohabitation in remarriage. Journal of Marriage and Family, 68, 261-274.
Todd M. Jensen, BS, is graduate research assistant, and Kevin Shafer, PhD, is assistant professor, School of Social Work, Brigham Young University, Provo, UT. Address correspondence to Kevin Shafer, School of Social Work, Brigham Young University, 2181 JFSB, Provo, UT 84602; e-mail:kevin_shafer@byu.edu.

Original manuscript received January 19, 2012

Final revision received April 6, 2012

Accepted May 17, 2012

Advance Access Publication March 24, 2013
Everyone Can Be Motivated

In all psychological and educational approaches, it is required in one way or the other that the client is motivated. This gives rise to the motivation paradox: those in most need of help receive the least support, or the converse: those who have the least need of help obtain most support.

To make matters worse, personnel who work with the most unmotivated clients often have the least resources at their disposal. This phenomenon may be called the personnel paradox.

Motivational Work describes a method which solves both the motivation paradox and the personnel paradox.

No-one is a hopeless case. It is possible to motivate all clients. It is not necessary to require motivation to be able to help somebody.
The method Motivational Work is aimed particularly at clients considered to be hopeless and not treatable. No-one is hopeless, Everyone can be motivated.
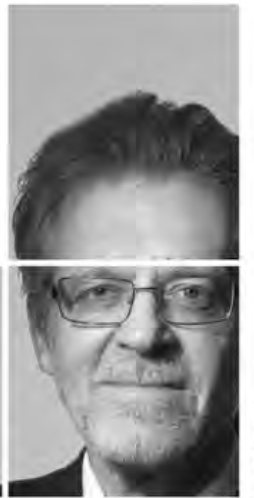

Per Revstedt

Lic. Psychologist

Lic. Psychotherapist

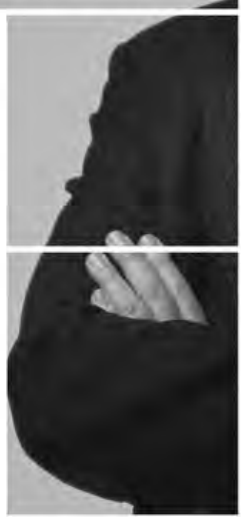

